\title{
State Urban and Community Forestry Program Funding, Technical Assistance, and Financial Assistance within the $\mathbf{5 0}$ United States
}

\author{
Richard J. Hauer and Gary R. Johnson
}

\begin{abstract}
This article describes the enabling legislation for technical and financial assistance, types and frequency of technical and financial assistance, and funding of urban \& community forestry (U\&CF) programs to the 50 United States. In 2002, \$30.7 million in federal and state money financed the 50 state U\&CF programs. Federal funding accounted for $60 \%$ ( $\$ 18.5$ million) and state funding was 33\% (\$10.2 million) of the total. Half of the \$36 million federal government U\&CF allocation in 2002 went directly to state U\&CF programs. State U\&CF programs distributed 38.3\% of program monies (from all funding sources) to local programs through grants. Remaining program monies were used to support state U\&CF programs through providing technical assistance, council administration, volunteer partnerships, and program administration. Nearly $60 \%$ of the state U\&CF coordinators suggested funding of their state U\&CF was inadequate to meet current needs and indicated a $60.9 \%$ mean increase in program funding was needed. All state coordinators believed their state U\&CF program would decline if federal funding was eliminated. Nearly one-third believed their state program would end and nearly half believed a severe reduction in the state program would occur if federal funding was eliminated. Only $42 \%$ of state U\&CF programs had enabling legislation that authorized financial and/or technical assistance. Other entities that provide U\&CF assistance were identified with the Cooperative Extension Service most frequently cited.
\end{abstract}

Key Words. Technical and financial assistance; urban and community forestry; urban forestry program capacity model.

Urban and community forests (U\&CF) produce identifiable and tangible benefits (i.e., environmental, economic, sociologic) that often surpass the costs of inputs used to establish and maintain them (Nowak and Dwyer 2000; Kuo 2003; McPherson 2003; Westphal 2003). Within the continental United States, there is an urban forest resource containing 3.8 billion trees with an estimated \$2.4 trillion value (Nowak et al. 2002). Although a vast array of data reveals that benefits surpass costs associated with $\mathrm{U} \& \mathrm{CF}$ programs, the impetus to establish $\mathrm{U} \& \mathrm{CF}$ programs is lacking in many communities (Kielbaso 1990; Tschantz and Sacamano 1994; Clark et al. 1997; Thompson and Ahern 2000; Dwyer et al. 2003; Elmendorf et al. 2003; Konijnendijk 2003; Schroeder et al. 2003; Hortscience and Aslan Group 2004). State and federal U\&CF programs have been created as a means to foster the development and enhancement of local U\&CF programs and efforts.

A regularly stated outcome of state and federal U\&CF programs is to help a community or local entity become selfsufficient through a developed ability or capacity. State and federal U\&CF programs regularly use, but do not explicitly define, capacity. Standard dictionaries define capacity as the ability to perform or produce, to do something, and an optimum amount that can be produced. As an example, since the mid-1990s, the U.S. Department of Agriculture Forest Service (USDA-FS) developed strategic goals or outcomes to "increase the capacity of state forestry agencies, local governments, and the private sector to create and implement local programs that will sustain and improve urban and community natural resources" and further increase capacity within the agency (USDA-FS 1996, 2002b, $2002 c)$. Hauer $(2005,2006)$ created three definitions of capacity for urban forestry programs and to describe the state of the urban forest based on available structure (i.e., components of a system such as policy, enabling mechanisms, people, biotic resources) to develop or maintain the urban forest at a given level. These three definitions include: Urban Forestry Program $\mathrm{Ca}$ pacity - the structure an urban forestry agency, entity, municipality, nonprofit organization, and others have in place to support urban forest development and sustainability at a local, regional, or national scale; Urban Forest Development Capacitythe ability to incrementally improve the state of the urban forest to a higher level with a given set of structure as inputs; and Urban Forest Sustainability Capacity - the level of structure as inputs needed to maintain the urban forest at a given state within a given time period. Increasing or building of capacity within local U\&CF programs is a goal of federal and state U\&CF programs through technical assistance, financial assistance, and education.

The USDS-FS described state U\&CF program activity with five terms: inactive, project, formative, developmental, and sustainable (Table 1). Local programs range widely across these categories (Hortscience and Aslan Group 2004; Hauer 2005; Hauer and Johnson 2008). Sustainable implies the structure within the urban forestry program, including such areas as financial, political, community participation, staffing, equipment, and contracting that are sufficient to perpetuate the current and foreseeable urban forest at a socially preferred level (Clark et al. 1997; Dwyer et al. 2003; Hauer 2005, 2006). In the United States, over half of the communities with a population exceeding 100 people had no U\&CF program in 2003 (Hauer 2005). During this same time period, less than $10 \%$ of communities had U\&CF programs rated as sustainable based on the USDA-FS Performance Measurement Accountability System (PMAS) evaluation 
Table 1. Definitions of Performance Measurement Accountability System (PMAS) levels used to rank community urban and community forestry capacity. ${ }^{z}$

\begin{tabular}{|c|c|}
\hline PMAS level & Description of PMAS level \\
\hline Project & $\begin{array}{l}\text { Project-level communities are those in which assistance to do projects such as Arbor Day, tree planting, grants, or one-time events are } \\
\text { taking place. These communities have not expanded from projects to program with infrastructure for conserving, establishing, or } \\
\text { managing trees, forests, greenspace, and related natural resources within their environments. }\end{array}$ \\
\hline Formative & $\begin{array}{l}\text { Formative-level communities have recognized that trees, forests, and greenspace are assets to their community and are initiating } \\
\text { community-based natural resource programs with the help of the urban and community forestry program technical or financial } \\
\text { assistance. Technical assistance activities under this stage include the establishment of citizen organizations and structures with interest } \\
\text { in trees, forests, and related natural resources in their community, discussions with community leaders, basic or more comprehensive } \\
\text { assessments of natural resources and/or conditions, Arbor Day celebrations, organized community meetings, networking, and } \\
\text { coordination. }\end{array}$ \\
\hline Developmental & $\begin{array}{l}\text { Developmental communities have initiated community-based forestry and natural resource-related programs and are pursuing additional } \\
\text { activities to improve and enhance these resources. Technical assistance activities include assisting citizen organizations and advisory or } \\
\text { governing organizations in planning, policy and budget development, meetings, workshops, urban natural resource inventories and } \\
\text { ecologic assessments, management plan and/or ordinance development, review of policies related to land use and development, and } \\
\text { engaging in partnership development. }\end{array}$ \\
\hline Sustained & $\begin{array}{l}\text { Sustained-level communities have a community-based forestry or natural resource program organized well enough such that } \\
\text { community-based organizations or municipal agencies are functioning on their own with appropriate support from multiple levels. } \\
\text { Annual planning, community leadership, and systematic approach to conservation and management of trees, forests, and related natural } \\
\text { resources characterize these communities. Technical assistance enhances existing programs but is more infrequent than previous levels. }\end{array}$ \\
\hline
\end{tabular}

${ }^{\mathrm{z}}$ Adapted from PMAS Desk Guide Ver. 10/2003 (www.fs.fed.us/spf/coop/library/PMAS\%20DeskGuide\%202004.pdf).

criteria. Finally, slightly more than one-third of communities still lack the structure to undertake and implement sustained $\mathrm{U} \& \mathrm{CF}$ programs. They are in some form of activity that increases from the project level (e.g., tree planting celebration or other one-time events), the formative level (e.g., formal recognition of U\&CF importance through ordinances, citizen input, and/or technical assistance), and finally the developmental level (e.g., further activities initiated that foster urban forests and other natural resources). These activity levels are precursors to a sustainable U\&CF program.

The USDA-FS and state U\&CF programs provide technical and financial assistance to local U\&CF programs in the United States (USDA-FS 2002a). This partnership has been evolving since the 1960s and assistance mechanisms have been used with the goal to build local U\&CF capacity (Unsoeld 1978; Biles and Deneke 1982; Casey and Miller 1988; Deneke 1992; Hauer 2005). Technical assistance and financial assistance through local capacity-building grants support local activities such as tree inventories, strategic planning, tree risk assessment, education, tree planting, tree removal, equipment purchases, and others.

State and federal technical and financial assistance to local urban forestry programs may enhance U\&CF capacity within local programs, foster development of the urban forest, and ultimately move communities toward a sustainable urban forest (Clark et al. 1997; Dwyer et al. 2003). Technical assistance and financial assistance lead to increased local urban forestry activity and urban forests (Still et al. 1996; Vitosh and Thompson 2000; Bird 2002; Hauer 2005, 2006). However, few studies have quantified the structure of state U\&CF programs (Andresen 1978; Casey and Miller 1988; Hortscience and Aslan Group 2004; Hauer 2005). This article identifies sources of state U\&CF funding and financial assistance and technical assistance to local U\&CF programs within the 50 United States.

\section{METHODS}

Urban forestry program capacity within the 50 state U\&CF programs in the United States was assessed through a selfadministered questionnaire for program year 2002. As a basis for the questionnaire, the study used the model Urban Forestry Pro- gram Capacity - the structure an urban forestry agency, entity, municipality, nonprofit organization, or others have in place to support urban forest development and sustainability at a local, regional, or national level (Hauer 2005; Hauer 2006). The structure for this article was collected through a questionnaire that ascertained enabling legislation for technical and financial assistance, types and levels of technical and financial assistance, and funding sources of the 50 state U\&CF programs. Results from this study are limited to the 50 state U\&CF programs in the United States.

The questionnaire was Beta-tested through five state U\&CF coordinators and two federal U\&CF staff with refinement based on their comments. The self-administered questionnaire was mailed to the entire population of 50 state U\&CF coordinators using a mailing list maintained by the USDA-FS. The District of Columbia and the eight territories of American Samoa, the Commonwealth of the Northern Mariana Islands, the Federated States of Micronesia, Guam, Palau, Puerto Rico, and the U.S. Virgin Islands were excluded from this study based on nonresponse to preliminary work associated with this study. Questionnaire delivery used elements of the Tailored Design Method (Dillman 2000). The delivery method involved: 1) sending a prenotice letter explaining the study purpose 4 business days before sending the questionnaire; 2) mailing the instrument with a cover letter explaining the importance of completing the questionnaire; 3 ) mailing a reminder postcard 10 days after sending the questionnaire; 4) resending the questionnaire to nonrespondents 1 month after the initial mailing; and 5) follow-up contacts to the remaining nonrespondents through an e-mail reminder, a brief message in the state U\&CF coordinator newsletter, and a final phone call. Responses from the questionnaire were entered into Microsoft Access 2002 (Microsoft, Redmond, WA) and descriptive statistics compiled using both SPSS version 11.5 (SPSS Inc., Chicago, IL) and Microsoft Excel 2002. The questionnaire and compiled descriptive summary statistics used in this study are found in Appendix 1 and Hauer (2005).

Nonresponse error and differences between responding and nonresponding states were tested using an independent samples t-test at the 0.05 probability level. State-reported data from 2002 
in the USDA-FS PMAS database (http://spfnic.fs.fed.us/ nicportal/default.cfm?action $=$ Login) was used to test for differences between responding and nonresponding states using all variables, including the number of communities in the state, communities in each of five activity levels (inactive, project, formative, developmental, and sustained), level of technical assistance to communities by project level and in aggregate, financial assistance provided by the federal government, statesupplied financial assistance, leveraged in-kind services, and project and outreach to culturally and economically diverse communities. A test for difference in population was further conducted using raw state population estimates and state rank for 2002 (U.S. Census Bureau 2004).

\section{RESULTS}

\section{Responses Obtained}

Forty-two of 50 questionnaires were returned (84\% response rate). All but one were useable questionnaires and included in the results (one state replied with no responses). Nonresponse error between responding and nonresponding states was absent for all PMAS data elements and for the 2002 state population. Thus, results from this study are representative of all 50 state $\mathrm{U} \& \mathrm{CF}$ programs. Nonitem response error (response to a question) was very low with $95 \%(n=39)$ to $100 \%(n=41)$ response to each question.

\section{Funding}

A variety of funding sources support state U\&CF programs ( $n=$ 41). These sources (and percent of states using a source) include the USDA-FS (100\%), state government $(61 \%)$, foundations and trust accounts (12.2\%), U.S. Department of Transportation TEA21 funds (9.8\%), and contracts and fees (2.4\%). Other identified sources of funding were state transportation funds, license plate fees, investor-owned utilities, local match, and Arbor Day sponsors. Two responding states noted (in an open-ended question) that the USDA-FS-consolidated payment system was used to attain a $100 \%$ match for all of the agency's State \& Private Forestry funding but not to fund the program. Consolidated payments occur through using overmatch in other USDA-FS cooperative programs (e.g., fire control, forest health, forest stewardship) with states.

An estimated $\$ 30.7$ million $(n=41)$ was used to fund the 50 state U\&CF programs in 2002 (Table 2). Of this, 60.2\% (\$18.5 million) came from federal USDA-FS funds and $33.1 \%$ (\$10.2 million) from state funds. The remaining funding came from foundation/trust funds and Federal TEA21 funds each at $2.9 \%$ (\$0.89 million for each), contracts/fees accounting for $0.3 \%$ ( $\$ 0.10$ million), and other sources for $0.6 \%$ ( $\$ 0.18$ million). Just over half (51.4\%) of the $\$ 36$ million federal allocation for U\&CF in fiscal year 2002 was delivered to state U\&CF programs. In addition to state U\&CF support, federal U\&CF monies are used for other programs and other areas (e.g., administration, conference support, technology transfer, research, congressional earmarks).

In response to adequacy of funding for the state U\&CF program $(n=39)$, the majority of state U\&CF coordinators believed funding is either inadequate $(53.8 \%)$ or very inadequate $(5.1 \%)$ to support identified needs. Only $5.1 \%$ thought funding was very adequate and $35.9 \%$ believed it was adequate. Those that thought funding was less than adequate suggested an average $60.9 \%$ (median, $40 \%$; range, $20 \%$ to $400 \%$ ) in additional funding above current levels was needed. Grants to local communities (13 states), staffing (eight states), and technical assistance (six states) were major items identified as affected by inadequate funding.

Federal support to states was critical for state U\&CF programs to continue at current levels. If federal funding was eliminated, none of the 41 respondents believed state programs would continue at current levels. Nearly one-third $(31.7 \%)$ thought the state U\&CF program would end, $48.8 \%$ responded the program would continue at a severely reduced level, and $19.5 \%$ believed a slight or moderate reduction in the state U\&CF program would occur. States $(n=40)$ neither use state-level funding to finance state U\&CF programs (40\%) nor specifically earmark funding through legislation $(35 \%)$. The states $(25 \%)$ that had a specific state government funding earmark responded that it was contingent on annual or biannual reauthorization (17.5\%), the baseline funding was not subject to periodic reauthorization $(2.5 \%)$, or other $(5 \%)$ means were used to earmark funding. Reduction in federal funding to the states would also affect local U\&CF programs $(n=40)$. Fourteen states $(35 \%)$ predicted a very high impact, 15 states $(37.5 \%)$ a high impact, eight states $(20 \%)$ a moderate impact, and the remaining three states $(7.3 \%)$ a very low impact.

\section{Enabling Legislation for Technical and Financial Assistance}

Less than half of the state U\&CF programs (41.5\%) had enabling legislation that authorized technical and/or financial assistance $(n=41)$. Of these, $76.5 \%$ authorize financial and $82.4 \%$ authorize technical assistance. A combined $58.8 \%$ of states with en-

Table 2. Sources of funding for $\mathbf{4 1}$ state urban and community forestry programs and extrapolated national estimate for funding sources.

\begin{tabular}{|c|c|c|c|c|c|c|c|}
\hline \multirow[b]{2}{*}{ Source of funding } & \multirow[b]{2}{*}{ Mean (\$) } & \multirow[b]{2}{*}{ Median (\$) } & \multicolumn{2}{|c|}{ Range (\$) } & \multirow[b]{2}{*}{ National estimate $^{\mathrm{z}}(\$)$} & \multirow[b]{2}{*}{ No. of states } & \multirow[b]{2}{*}{ Percent using source } \\
\hline & & & Low & High & & & \\
\hline Federal & 369,832 & 280,000 & 179,500 & $1,081,898$ & $18,491,600$ & 41 & 100.0 \\
\hline Contract/fee & 85,000 & 85,000 & 85,000 & 85,000 & 103,659 & 1 & 2.4 \\
\hline Foundation/trust fund & 146,550 & 183,000 & 8,250 & 295,000 & 893,598 & 5 & 12.2 \\
\hline Federal transportation & 182,500 & 140,000 & 100,000 & 350,000 & 890,244 & 4 & 9.8 \\
\hline
\end{tabular}

${ }^{\mathrm{z} E x t r a p o l a t i o n}$ for all 50 states from sample $(n=41)$ in this study. Extrapolation calculated from: extrapolated value $=($ mean value $) *(\%$ using source $*(50)($ e.g., state extrapolation $=334,091 * 0.61 * 50=\$ 10,185,701)$. 
abling legislation authorize both assistance forms, $23.5 \%$ enable technical assistance only, and $17.6 \%$ enable financial assistance only. The earliest reported legislation enabling a state U\&CF program was the California Urban Forest Act of 1978. On average, legislation authorizing financial assistance was passed in 1992 (median 1993) and technical assistance passed in 1988 (median 1989). Of the $58.5 \%$ of states that did not have enabling legislation, approximately equal numbers suggested that either general forestry enabling legislation (11 states) or the federal $\mathrm{U} \& \mathrm{CF}$ program (13 states) were used to justify the state $\mathrm{U} \& \mathrm{CF}$ program and assistance provided locally.

The 41 responding programs provided a mean average of 356 (median, 240; range, 35 to 1509) technical and financial assists annually within a state. A mean average 166 (median, 110; range, 16 to 650 ) communities received one or more technical assists annually. Financial assistance using state and federal funding was delivered to a mean average 31 (median, 29; range, 0 to 95 ) communities annually.

\section{Financial Assistance}

Grants to communities and others to conduct U\&CF projects were one use of state U\&CF program funds $(n=41)$. Federal Cooperative Forestry Assistance Challenge Grants were provided by $82.9 \%$ of states with a mean average $\$ 160,568$ (median, $\$ 125,000$; range, $\$ 9000$ to $\$ 535,000$ ) offered by states (Table 3). Extrapolated nationally, $\$ 6,657,693$ in grant funding was dispensed, which was approximately $36 \%$ (median, $34.4 \%$; range, $0 \%$ to $100 \%$ ) of the federal U\&CF funding allocated to states. State funds were also allocated locally through grants in $39 \%$ of states $(n=41)$. Of this, a mean average $\$ 251,574$ (median, $\$ 166,000$; range, $\$ 0$ to $\$ 1,125,000)$ was spent with a national extrapolation of $\$ 4,908,761$ by states with grants. Nationally, grants from state money were $48.2 \%$ (median, $43.9 \%$; range, $0 \%$ to $88 \%$ ) of total state funds allocated to the U\&CF program. Recipient matching through money and in-kind services exceeded grant amounts by approximately $20 \%$. National leverage of grants (i.e., match by nonfederal sources) was $\$ 8$ million for Federal Cooperative Assistance money and \$5.7 million for state money. Overall, $95.1 \%$ of states $(n=41)$ reported that they provided financial assistance through grants with national estimates of $\$ 11.8$ million for total money and \$14.6 million with leveraged money. State funding for grants rely on a variety of sources, including dedicated allocations (50\% of states), state government general fund $(35.7 \%)$, foundation/trust fund $(28.6 \%)$, and other sources $(28.6 \%)$. Other identified sources were public-owned utilities, dedicated sales tax, Federal DOT TEA21 funds, and air pollution fines.

\section{Technical Assistance}

State U\&CF programs vary in the frequency of providing 27 forms of technical assistance (Table 4). The most frequently provided types of technical assistance included Arbor Day activities $(84.2 \%)$, species selection $(78.9 \%)$, information on funding sources $(75.7 \%)$, and Tree City USA programming $(70.3 \%)$. A moderate number of states frequently provide outreach through a newsletter $(62.2 \%)$ or training programs for professionals $(55.3 \%)$, staff $(47.4 \%)$, and volunteers $(42.1 \%)$. Activities that were least likely to be frequently provided include assistance for establishing nursery facilities $(0 \%)$, developing disaster preparedness response plans $(5.4 \%)$, wood utilization assistance $(8.1 \%)$, providing nursery stock $(13.9 \%)$, comprehensive natural resource planning (14.3\%), and woodland conservation/ protection planning $(16.7 \%)$. Assistance was also provided frequently at a low level with master street tree planning (23.7\%), tree risk management (26.3\%), shade tree ordinances (28.9\%), comprehensive U\&CF program planning (31.6\%), developing maintenance programs (36.8\%), and tree inventories (39.4\%).

The lead U\&CF agency in a state was not the only entity to offer U\&CF technical assistance (Table 5). Others include the Cooperative Extension Service (CES), Natural Resources and Conservation Service (NRCS), State Agricultural Departments (DOA), State Departments of Transportation (DOT), State Natural Resources and Conservation Departments (NR), Professional Urban Forestry Organizations (PRO), nonprofit organizations (NPO), State Land Grant Universities (SLG), Soil and Water Conservation Districts (SWCD), and Resource Conservation and Development Councils (RCD). The level of assistance varied by agency or entity with the CES cited as most likely to provide frequent assistance $(52.6 \%)$. Almost $90 \%$ indicated some level of frequent or occasional assistance was provided by CES. In contrast, the state DOA or DOT was less likely to provide U\&CF assistance with $69.7 \%$ of DOAs and $57.1 \%$ of DOTs identified as rarely or never involved. However, a frequent level of technical assistance was typically provided by a DOA (which was similar to findings with a NR agency) if it administered the state U\&CF program. Over two-thirds of PRO (76.5\%), NPO (73\%), and SLG $(68.8 \%)$ provided occasional or frequent U\&CF technical assistance. Agencies including NRCS, SWCD, and RCD were occasional to frequent contributors to U\&CF programs in approximately $50 \%$ of states. A few states indicated that RCDs were readily used to deliver financial assistance programs.

\section{DISCUSSION}

State U\&CF forestry programs continue to be perceived as underfunded. Results from this study and past programmatic needs

Table 3. Financial assistance within state urban and community forestry programs in the 50 United States and extrapolated national estimate for various financial assistance sources.

\begin{tabular}{|c|c|c|c|c|c|c|c|}
\hline \multirow[b]{2}{*}{ Assistance source and leverage } & \multirow[b]{2}{*}{ Mean $(\$)$} & \multirow[b]{2}{*}{ Median (\$) } & \multicolumn{2}{|c|}{ Range (\$) } & \multirow[b]{2}{*}{ National estimate ${ }^{\mathrm{z}}(\$)$} & \multirow[b]{2}{*}{ No. of states } & \multirow[b]{2}{*}{ Percent using source } \\
\hline & & & Low & High & & & \\
\hline Federal money & 160,568 & 125,037 & 9,000 & 535,000 & $6,657,693$ & 34 & 82.9 \\
\hline State money & 251,574 & 166,500 & 0 & $1,125,000$ & $4,908,761$ & 16 & 39.0 \\
\hline State leverage & 295,257 & 153,945 & 0 & $1,175,000$ & $5,761,109$ & & \\
\hline Total money & 247,833 & 189,713 & 9,000 & $1,464,000$ & $11,772,091$ & 38 & 95.0 \\
\hline
\end{tabular}

${ }^{\mathrm{z} E x t r a p o l a t i o n}$ for all 50 states from sample $(n=38)$ in this study. Extrapolation calculated from: extrapolated value $=($ mean value $) *(\%$ using source $*(50)($ e.g., state extrapolation $=251,574 * 0.39 * 50=\$ 4,908,761)$. 
Table 4. Frequency of technical assistance provided by state urban and community forestry (U\&CF) programs in 2002 within the 50 United States.

\begin{tabular}{|c|c|c|c|c|c|c|}
\hline \multirow[b]{2}{*}{ Types of U\&CF assistance } & \multicolumn{5}{|c|}{ Frequency of assistance } & \multirow[b]{2}{*}{ Ranking index ${ }^{z}$} \\
\hline & Frequent (3) & Occasional (2) & Rarely (1) & Never $(0)$ & Do not know & \\
\hline Arbor Day activities & 32 & 6 & 0 & 0 & 0 & 2.84 \\
\hline Information on funding sources & 28 & 8 & 1 & 0 & 0 & 2.73 \\
\hline Tree City USA & 26 & 11 & 0 & 0 & 0 & 2.70 \\
\hline Training programs for staff & 18 & 19 & 1 & 0 & 0 & 2.45 \\
\hline Training programs for volunteers & 16 & 20 & 2 & 0 & 0 & 2.37 \\
\hline Establishing tree commissions/boards & 14 & 20 & 3 & 0 & 0 & 2.30 \\
\hline Insect and disease evaluation and/or control & 18 & 13 & 7 & 0 & 0 & 2.29 \\
\hline Developing tree maintenance programs & 14 & 22 & 1 & 1 & 0 & 2.29 \\
\hline Special projects & 15 & 17 & 5 & 0 & 1 & 2.27 \\
\hline Tree inventory guidance & 15 & 18 & 5 & 0 & 0 & 2.26 \\
\hline Shade tree ordinances & 11 & 22 & 4 & 1 & 0 & 2.13 \\
\hline Comprehensive U\&CF program planning & 12 & 15 & 8 & 3 & 0 & 1.95 \\
\hline Master street tree planning & 9 & 17 & 9 & 3 & 0 & 1.84 \\
\hline Comprehensive natural resource planning & 5 & 12 & 12 & 6 & 3 & 1.46 \\
\hline Landscaping & 1 & 20 & 7 & 9 & 1 & 1.35 \\
\hline Woodland construction and protection planning & 6 & 7 & 14 & 9 & 2 & 1.28 \\
\hline Disaster preparedness response planning & 2 & 13 & 15 & 7 & 1 & 1.27 \\
\hline Providing nursery stock & 5 & 9 & 11 & 11 & 1 & 1.22 \\
\hline Wood utilization & 3 & 9 & 17 & 8 & 1 & 1.19 \\
\hline Establishing nursery facilities & 0 & 11 & 13 & 13 & 0 & 0.95 \\
\hline Overall & 375 & 400 & 158 & 76 & 11 & 2.06 \\
\hline
\end{tabular}

${ }^{\mathrm{z}}$ Ranking index derived from the proportional frequency of assistance.

analyses suggest that for many state programs, a reliance on federal support exists. For example, the National Association of State Foresters (NASF) determined in 1988 that $\$ 44.6$ million in funding (federal, state, local, and other) was needed to implement effective state-level urban forestry programs (Casey 1988; Casey and Miller 1988; NASF 1988; Reichenbach 1988). Adjusting for inflation (Producer Price Index for All Commodities), this estimate is a real $\$ 54.7$ million in 2002 . By comparison, the
National Alliance for Community Trees (NACT) and NASF proposed similar \$55 and \$57 million federal budgets for U\&CF in 2002 (NACT 2001; NASF 2002). State U\&CF coordinators in this study suggested a mean $60.9 \%$ increase or $\$ 57.9$ million in funding was necessary to meet needs in 2002. Funding proposals by the state U\&CF coordinators, NASF, and NACT similarly suggest an increase in federal funding of approximately $\$ 20$ million to meet identified needs. The 2006 fiscal year $\$ 28.875$

Table 5. Frequency of agencies and entities other than the lead agency for urban and community forestry (U\&CF) in a state to provide technical assistance in $\mathbf{2 0 0 2}$ within the $\mathbf{5 0}$ United States.

\begin{tabular}{|c|c|c|c|c|c|c|}
\hline \multirow{2}{*}{$\begin{array}{l}\text { Other agencies or entities that provide } \\
\text { U\&CF technical assistance in your state }\end{array}$} & \multicolumn{5}{|c|}{ Frequency that the agency provides assistance } & \multirow[b]{2}{*}{ Ranking index ${ }^{z}$} \\
\hline & Frequent (3) & Occasional (2) & Rarely (1) & Never $(0)$ & Do not know (9) & \\
\hline Cooperative Extension Service & 20 & 14 & 3 & 1 & 1 & 2.39 \\
\hline Natural Resources \& Conservation Service & 2 & 18 & 13 & 3 & 3 & 1.53 \\
\hline State Agriculture Department & 4 & 6 & 16 & 7 & 5 & 1.21 \\
\hline State Natural Resources/Conservation Department & 12 & 3 & 8 & 9 & 4 & 1.56 \\
\hline State Department of Transportation & 4 & 11 & 11 & 9 & 3 & 1.29 \\
\hline Professional Urban Forestry Organizations & 14 & 12 & 6 & 2 & 3 & 2.12 \\
\hline Nonprofit organizations & 17 & 10 & 8 & 2 & 2 & 2.14 \\
\hline State Land Grant University & 12 & 10 & 10 & 0 & 6 & 2.06 \\
\hline Soil and Water Conservation Districts & 5 & 11 & 13 & 3 & 7 & 1.56 \\
\hline Resource Conservation \& Development Council & 6 & 8 & 16 & 1 & 7 & 1.61 \\
\hline Other (American Society of Landscape Architects) & 0 & 1 & 0 & 0 & 0 & 2.00 \\
\hline Overall & 96 & 103 & 104 & 37 & 41 & 1.76 \\
\hline
\end{tabular}

\footnotetext{
${ }^{\mathrm{z}}$ Ranking index derived from proportional frequency of assistance.
} 
million federal allocation for U\&CF only widens the gap between suggested needs and funding.

The program expenditures in this study, however, do not account for money spent by state entities other than the agency that undertakes the lead U\&CF role in the state. The magnitude of monetary investments outside of the state $U \& C F$ program can be illustrated through introduction of new exotic species and established exotic species, their impact, and control costs associated with urban forests. Response to emerald ash borer (Agrilus planipennis) to date has exceeded $\$ 100$ million (USDA 2006). Federal funding for Asian Longhorned (Anoplophora glabripennis) beetle eradication since 1997 was over \$200 million with an estimated $\$ 300$ million cost for complete eradication (Weiner and Maloney 2006). These expenditures are used to protect an ALB-susceptible urban forest resource with a $\$ 669$ billion compensatory value (Nowak et al. 2001). Some of the exotic pest funds are used to support technical and financial assistance at the local level in ways similar to the state U\&CF program.

The USDA-FS Northeastern Area State and Private Forestry (NA SP\&F) unit envisioned that state and local U\&CF entities would greatly increase their U\&CF capacity through state and local monetary resources within 3 years of resultant funding from the 1990 Farm Bill (USDA-FS 1990). Federal funding would then decrease as states and local entities began to fund a greater proportion of their programs. This ambitious goal has yet to be realized, although federal funding to states has increased in both real and nominal money through federal U\&CF allocations. Over the same time period, state funding for U\&CF programs (as a percentage of the total forestry budget) in the agency administering the U\&CF program declined from $2.8 \%$ in 1994 to $2.6 \%$ in $1996,1.8 \%$ in 1998, and $1.9 \%$ in 2002 (NASF undated). In 2002 , nearly $40 \%$ of states did not directly match federal funding through state government funding. Rather, the use of consolidated payments and leverage from U\&CF programs within the state were used as money sources to meet the match criteria. Two respondents also directly noted through an open-ended question that consolidated payments were negatively affecting state levelsponsored funding. Thus, although the USDA-FS NA SP\&F believed that the federal role would continue to decline over time, many state U\&CF programs rely on federal support.

Before 1990, state U\&CF programs provided primarily technical assistance. For example, only $39 \%$ of states offered financial assistance programs for local U\&CF efforts (Casey and Miller 1988). In 2002, $95 \%$ of state programs did so. Grant assistance for local U\&CF programs was a common use of federal and state U\&CF program funds. Few studies have asked whether U\&CF grant programs are effective in increasing local capacity for U\&CF. Still et al. (1996) in Pennsylvania and Bird (2002) in North Dakota found that cities or towns that applied for grants were more likely to have tree ordinances, inventories, or management plans than nonapplicants. Communities that never applied for state funding either lacked community support for tree programs or rated trees as a lower priority. Communities with funded projects tend to have community support. In Iowa, Vitosh and Thompson (2000) found grants greatly increased community forestry activities and attributes such as volunteer tree planting groups, tree boards, inventories, management plans, shade tree ordinances, and line item funding for tree-related activities. The retention of U\&CF activity over time can decrease as priorities change and inputs such as funding and other forms of assistance decline.
Have the federal and state U\&CF programs resulted in improved local urban forestry efforts? The Federal PMAS data from 1997 to 2004 identified a $2.1 \%$ increase in local U\&CF program activity with a corresponding $2.1 \%$ decline annually in communities not conducting U\&CF activities (Hauer 2005, 2006). Corresponding increases in project, formative, developmental, and sustained communities also occurred, suggesting an increased local capacity within U\&CF programs. Hauer (2005, 2006) found federal financial support of the state U\&CF program, technical assistance to local programs, and financial assistance to local programs explained $73 \%\left(\mathrm{R}^{2}\right.$ adj $)$ of the increase in urban forestry activity at the local level.

Government can influence resource management through passive (e.g., technical assistance, education programs, voluntary guidelines), proactive (e.g., financial incentives, tax incentives), and controlling (e.g., regulatory) roles (Cheng and Ellefson 1993). Baughman (1980) contended that government involvement in urban forestry must contribute to social welfare through economic efficiency and stability and be equitable. State U\&CF programs have traditionally used passive and proactive roles in attempting to influence U\&CF at a more local level (Casey and Miller 1988; Hauer 2005). However, regulatory activities are used in the management of urban forests at federal, state, and local levels. Ordinances, tree protection statutes, zoning, plant protection acts and nursery stock regulation, exotic pest quarantines, and tree planting requirements associated with development and redevelopment are examples.

The state U\&CF program is not the only entity providing $\mathrm{U} \& \mathrm{CF}$ assistance. This was consistent with findings of Ellefson et al. $(2001,2002)$ in which programs and organizations affecting the use, management, and protection of forests were found in many agencies among states. The cooperative extension service, state land grant universities, professional organizations, and nonprofit organizations commonly conduct U\&CF programming. Some such as the Cooperative Extension Service have been involved in urban forestry through direct and indirect means for several decades (Neuhauser 1973). The connections and partnerships within U\&CF in the United States are extensive with over 1218 different organizations at local, state, and federal levels identified (Hortscience and Aslan Group 2004). Federal agencies beyond the USDA-FS also periodically provide U\&CF assistance, including the Animal Plant Health Inspection Service, Department of Commerce, Department of Transportation, Federal Emergency and Management Agency, Small Business Administration, and Housing and Urban Development (Miller 1997).

Finally, findings from this study were extrapolated to account for the funding to 50 state U\&CF programs. Results from federal expenditures ( $\$ 18.5$ million) from this study were generally consistent with the $\$ 18.3$ million documented by the U.S. House of Representatives (2004) and \$18.2 million documented in PMAS for the 50 states. Temporary federal reallocations in response to wild-fire control caused withholding of money from two state U\&CF programs in 2002 with funding actually received in 2003. Comparisons to funding in 2001 and 2003 for these two states suggest a \$0.4 million underreporting in PMAS for year 2002 and plausibly an actual $\$ 18.6$ million. State funding from this study was substantially lower (\$10.2 million) than the PMASreported $\$ 14.5$ million. This discrepancy $(42.2 \%$ more reported in PMAS) is explained by subtracting the reported money from the PMAS amounts for states that reported $\$ 0$ in this study (e.g., 
consolidated payments, local in-kind). States that responded no state funds were allocated (\$2.7 million) and those reporting funding through foundation/trust and contract/fees money $(\$ 1$ million) in this study leaves a $\$ 10.8$ million state estimate from PMAS. This compares well to this studies extrapolated value of $\$ 10.2$ million.

Acknowledgments. We thank Dr. Alan Ek, Dr. Jennifer Juzwik, Dr. Mike Kilgore, and two anonymous reviewers for their constructive comments on the earlier draft of this paper.

\section{LITERATURE CITED}

Andresen, J.W. 1978. Urban forestry today, pp. 3-8. In: McBride, J., and R. Beatty (Eds.). Proceedings of the California Symposium on Urban Forestry, May 19-20, 1978, Berkeley, CA.

Baughman, M.J. 1980. The role of government in urban forestry, pp. 302-306. In: Proceedings of the 1979 Convention of the Society of American Foresters. Society of American Foresters, Washington, DC.

Biles, L.E., and F.J. Deneke. 1982. Urban forestry programs begins fifth year. Journal of Arboriculture 8:154-156.

Bird, J. 2002. Pass-through Grants From Federal Sources to State Agencies as an Effective Tool to Develop Sustainable Community Forestry Programs at the Local Level. Unpublished manuscript. North Dakota State Forest Service, Bismarck, ND. 42 pp.

Casey, C.J. 1988. State Government Involvement in Community Forestry: A Survey and a Proposal for Development of a State Urban Forestry Assistance Program in Wisconsin. M.S. Thesis. University of Wisconsin-Stevens Point. 134 pp.

Casey, C.J., and R.W. Miller. 1988. State government involvement in community forestry: A survey. Journal of Arboriculture 14:141-144.

Cheng, A.S., and P.V. Ellefson. 1993. State Programs Directed at the Forestry Practices of Private Landowners: Program Administrators' Assessment of Effectiveness. Staff Paper Series \#8. Department of Forest Resources, University of Minnesota. $32 \mathrm{pp}$.

Clark, J.R., N.P. Matheny, G. Cross, and V. Wake. 1997. A model of urban forest sustainability. Journal of Arboriculture 23:17-30.

Deneke, F.J. 1992. A history of federal funding, pp. 188-189. In: Rodbell, P.D. (Ed.). Proceedings of the Fifth National Urban Forest Conference, Los Angeles, November 1991. American Forestry Association, Washington, DC.

Dillman, D.A. 2000. Mail and Internet Surveys: The Tailored Design Method. John Wiley and Sons, New York, NY. 464 pp.

Dwyer, J.F., D.J. Nowak, and M.H. Noble. 2003. Sustaining urban forests. Journal of Arboriculture 29:49-55.

Ellefson, P.V., R.J. Moulton, and M.A. Kilgore. 2001. Programs and Organizations Affecting the Use, Management, and Protection of Forests: An Assessment of Agencies Located Across the Organizational Landscape of State Governments. Department of Forest Resources, University of Minnesota, St. Paul, MN. 119 pp.

2002. An assessment of state agencies that affect forests. Journal of Forestry 100:35-41.

Elmendorf, W.F., V.J. Cotrone, and J.T. Mullen. 2003. Trends in urban forestry practices, programs, and sustainability: Contrasting a Pennsylvania, U.S., study. Journal of Arboriculture 29:237-248.

Hauer, R.J. 2005. Urban Forest and Urban Forestry Capacity: Defining Capacity and Models of Capacity Building. Doctoral Dissertation. Department of Forest Resources, University of Minnesota. www. uwsp.edu/cnr/faculty/hauer/Files/Hauer\%20Dissertation.pdf (accessed 3/7/2007).

2006. Urban forestry capacity building and models, pp. 1-24. In: Phillips, V.D., and R. Tschida (Eds.). Proceedings of the 4th International Conference on Environmental Management for Sustainable Universities, June 26-30, 2006. Global Environmental Management Education Center, College of Natural Resources, University of Wisconsin-Stevens Point, WI.
Hauer, R.J., and G.R. Johnson. 2008. Approaches within the 50 United States to meeting federal requirements for urban and community forestry assistance programs. Arboriculture and Urban Forestry 34:74-83.

Hortscience and Aslan Group. 2004. Assessment of the USDA Forest Service Urban \& Community Forestry Program. Prepared for the National Urban \& Community Forestry Advisory Council, USDA Forest Service. Hortscience, Pleasanton, CA. 47 pp with Appendices. www.treelink.org/linx/?navSubCatRef $=58$ (accessed 3/7/2007).

Kielbaso, J.J. 1990. Trends and issues in city forests. Journal of Arboriculture 16:69-76.

Konijnendijk, C.C. 2003. A decade of urban forestry in Europe. Forest Policy and Economics 5:173-186.

Kuo, F.E. 2003. The role of arboriculture in a healthy social ecology. Journal of Arboriculture 29:148-155.

McPherson, E.G. 2003. Urban forestry the final frontier. Journal of Forestry 101:20-25.

Miller, R.W. 1997. Urban Forestry: Planning and Managing Urban Greenspaces. 2nd Edition. Prentice Hall, New York, NY. 502 pp.

NACT. 2001. Briefing on the Federal Urban and Community Forestry Program. National Alliance for Community Trees, College Park, MD. www.americanforests.org/downloads/fp/policyviews/national_ alliance_for_community_trees.pdf (accessed 3/7/2007). 4 pp.

NASF. 1988. State Foresters Response to Urban Forestry Questionnaire. National Association of State Foresters, Washington, DC. 52 pp.

2002. Fiscal Year 2002: State \& Private Forestry (S\&PF) \& Related Forestry Programs Budget Proposals. National Association of State Foresters, Washington, DC. www.stateforesters.org/ (accessed 12/4/2006).

- Undated. State Forestry Statistics. National Association of State Foresters, Washington, DC. www.stateforesters.org/SFstats.html (accessed 3/7/2007)

Neuhauser, W.G. 1973. Cooperative extension and urban forestry, pp. 30-31. In: Miller, H.C. (Ed.). Proceedings Urban Forestry Conference, March 12-15, 1973. State University of New York, College of Environmental Science and Forestry, Syracuse, NY.

Nowak, D.J., D.E. Crane, and J.F. Dwyer. 2002. Compensatory value of urban trees in the United States. Journal of Arboriculture 28:194-199.

Nowak, D.J., and J.F. Dwyer. 2000. Understanding the benefits and costs of urban forest ecosystems, pp. 11-22. In: Kuser, J.E. (Ed.). Handbook of Urban and Community Forestry in the Northeast. Kluwer Academic/Plenum Publishers, New York, NY.

Nowak, D.J., J.E. Pasek, R.A. Sequeira, D.E. Crane, and V.C. Mastro. 2001. Potential effect of Anoplophora glabripennis (Coleoptera: Cerambycidae) on urban trees in the United States. Journal of Economic Entomology 94:116-122.

Reichenbach, M.R. 1988. Perspectives gained from the national urban forestry assessment: Forestry a community tradition, pp. 392-395. In: Healthy Forests, Healthy World, Proceedings of the 1988 Society of American Foresters National Convention, Rochester, NY. Society of American Foresters, Bethesda, MD.

Schroeder, H.W., T.L. Green, and T.J. Howe. 2003. Community tree programs in Illinois, U.S.: A statewide survey and assessment. Journal of Arboriculture 29:218-225.

Still, D., B. Fair, and H. Gerhold. 1996. Community forestry grants in Pennsylvania: How effective are they. Journal of Forestry 94:26-30.

Thompson, R.P., and J.J. Ahern. 2000. The State of Urban and Community Forestry in California: Status in 1997 and Trends Since 1988. Technical Report Number 9. Urban Forest Ecosystems Institute. California Polytechnic State University, San Luis Obispo, CA. 48 pp.

Tschantz, B.A., and P.L. Sacamano. 1994. Municipal Tree Management in the United States. Davey Research Group and Communication Research Associates, Inc. Report, Kent, OH. 58 pp.

Unsoeld, O. 1978. Legislative History of Urban Forestry: An Analysis. U.S. Department of Agriculture, Cooperative Forestry Internal Report. Washington, DC. 29 pp. 
U.S. Census Bureau. 2004. Annual Estimates of the Population for the United States and States, and for Puerto Rico: 1 April 2000 to 1 July 2003 (NST-EST2003-01). www.census.gov/popest/states/NST-annest.html (accessed 3/7/2007).

U.S. House of Representatives. 2004. A Report to the Committee on Appropriations U.S. House of Representatives on the U.S. Forest Service Urban and Community Forestry Program. Surveys and Investigations Staff, Committee on Appropriations, The U.S. House of Representatives, March 2004. www.treelink.org/linx/ ?navSubCatRef $=58$ (accessed 3/7/2007). 28 pp.

USDA. 2006. USDA announces additional \$7.6 million to stop the spread of emerald ash borer in Illinois. U.S. Department of Agriculture, Release No. 0260.06. www.usda.gov/wps/portal/ usdahome $?$ contentidonly $=$ true $\&$ contentid $=2006 / 07 / 0260 . x m l \quad($ accessed 3/7/2007)

USDA-FS. 1990. Urban Forestry Concept Paper. NA-GR-22. USDA Forest Service, Northeastern Area State and Private Forestry, Radnor, PA. 15 pp.

1996. Urban and Community Forestry on Course Into the Future, Vital Communities Through Healthy Ecosystem-A Strategic Direction. U.S. Department of Agriculture, Forest Service, Washington, DC. $12 \mathrm{pp}$

2002a. Cooperative Forestry Assistance Act of 1978. www.fs. fed.us/spf/coop/library/CFAA.pdf (accessed 3/7/2007).

. 2002b. Strengthening Forest Service and State Leadership in the Care of Urban and Community Forest Resources. U.S. Department of Agriculture, Forest Service. www.fs.fed.us/ucf/ action_plan.htm (accessed 3/7/2007).

2002c. Urban and Community Forestry Technology Transfer: National Strategy for 2002-2005. U.S. Department of Agriculture, Forest Service. FS-722. Washington, DC. 18 pp. www.fs.fed.us/ucf/ publications/index.shtml (accessed 3/7/2007).

Vitosh, M.A., and J.R. Thompson. 2000. Iowa communities benefit from an externally funded tree-planting program. Journal of Arboriculture 26:114-119.

Weiner, A.D., and C.B. Maloney. 2006. Longhorned Beetle, Shortchanged City: The Asian Longhorned Beetle in the Big Apple. U.S. House of Representatives, prepared by the Offices of Congressman Anthony D. Weiner and Congresswoman Carolyn B. Maloney. www. house.gov/weiner/report-asianbeetle-05262006.pdf (accessed 3/7/ 2007). 5 pp.

Westphal, L.M. 2003. Urban greening and social benefits: A study of empowerment outcomes. Journal of Arboriculture 29:137-147.

Richard J. Hauer (corresponding author)

Assistant Professor of Urban Forestry

College of Natural Resources

University of Wisconsin-Stevens Point

Stevens Point, WI 54481, U.S.

rhauer@uwsp.edu;Richard.Hauer@uwsp.edu

Gary R. Johnson

Professor of Urban and Community Forestry

College of Food, Agricultural and Natural Resource Sciences

Department of Forest Resources

University of Minnesota

1530 Cleveland Avenue North

St. Paul, MN 55108, U.S.

Résumé. Cet article décrit la législation en cours concernant l'assistance technique et financière, les types et la fréquence de l'assistance technique et financière, et les sources de fonds des programmes de foresterie urbaine des 50 états des États-Unis. En 2002, 30,7 millions de dollars en provenance du fédéral et des états ont servis à financer ces programmes au sein des 50 états. Les fonds fédéraux comp- taient pour $60 \%$ (18,5 millions de dollars) et l'argent provenant des états comptait pour $33 \%$ de la somme totale. La moitié des 36 millions de dollars d'allocation du gouvernement fédéral en 2002 est allé directement aux programmes d'état en foresterie urbaine. Ces programmes ont distribué $38,3 \%$ des fonds en argent (des différentes sources de fonds) vers les programmes locaux sous la forme de subventions. Les montants restants ont été utilisés pour supporter les programmes d'état en foresterie urbaine sous la forme d'assistance technique, d'assistance au conseil d'administration, de partenariat volontaire et d'administration de programme. Près de $60 \%$ des coordonnateurs des programmes d'état ont mentionné que le financement à leur programme était inadéquat à rencontrer les besoins courants et ils ont indiqué qu'il faudrait une augmentation moyenne de $60,9 \%$ des sommes. Tous les coordonnateurs d'état croyaient que leur programme d'état allait décliner si le financement fédéral était éliminé. Près du tiers croyait que leur programme d'état allait être supprimé et près de la moitié estimait qu'il allait y avoir une sévère réduction de leur programme d'état si le financement fédéral était retiré. Seulement $42 \%$ des programmes d'état en foresterie urbaine avaient une législation en vigueur qui autorisait le financement et/ou l'assistance technique. D'autres entités qui fournissent de l'assistance financière aux programmes de foresterie urbaine ont été identifiées et le Cooperative Service Extension est celui qui est le plus cité.

Zusammenfassung. Dieser Artikel beschreibt wegbereitende Gesetzgebung für technische und finanzielle Unterstützung, Arten und Frequenz der technischen und finanziellen Unterstützung sowie der Budgetierung von Forstprogrammen in den 50 vereinigten Staaten. 2002 standen für die 50 Forstprogramme \$ 30.6 Millionen zur Verfügung. Bundesmittel waren dabei $60 \%$ (\$ 18.5 Millionen) und Staatsmittel $33 \%$ (\$ 10.2 Millionen). Die Hälfte des \$ 36 Millionen-Bundesetats wanderten in 2002 direkt in Forstprogramme. Die staatlichen Forstprogramme wiesen durch Kredite 38,3\% der Mittel den lokalen Programmen zu. Die übrigen Mittel wurden darauf verwendet, staatliche Programme durch technische Unterstützung, Administration, Freiwilligenprogramme und Programmadministration zu unterstützen. Fast $60 \%$ der Programm-Koordinatoren gaben an, dass die bewilligten Mittel für ihr Programm unzureichend seien und deuteten an, dass eine durchschnittliche Steigerung von $60,9 \%$ erforderlich ist. Alle Koordinatoren glauben, dass ihr Programm zusammenbrechen würde bei der Mittelbegrenzung. Nahezu ein Drittel glauben, dass ihr Programm enden würde und fast die Hälfte glaubt, dass schwere Einkürzung des Programmes die Folge wäre, wenn die Bundesmittel wegfielen. Nur $42 \%$ der staatlichen Forstprogramme hatten eine wegbereitende gesetzliche Unterstützung, die technische und/oder finanzielle Assistenz ermöglichen würde. Andere Träger, die Unterstützung boten, wurden mit dem Cooperative Extension Service identifiziert,

Resumen. Este artículo describe la legislación permitida para la asistencia financiera y técnica, tipos y frecuencia de ayuda, y fondos de programas de dasonomía urbana y comunitaria (U\&CF) a los 50 estados en la USA. En 2002, se aportaron \$30.7 millones de dólares en financiamiento federal y estatal a estos programas. La ayuda federal respondió por el $60 \%$ y la estatal fue del $33 \%$ del total. La mitad de los aportes federales en 2002 fueron directamente a los programas estatales de U\&CF. Los programas estatales distribuyeron $38.3 \%$ de los fondos a los programas locales a través de subvenciones. Los remanentes fueron usados para soportar programas estatales a través de asistencia técnica, voluntarios y programas de administración. Aproximadamente el $60 \%$ de los coordinadores de los U\&CF sugirieron que los apoyos para sus estados fueron inadecuados de acuerdo a sus necesidades e indicaron que se requería un aumento del $60.9 \%$. Todos los coordinadores están de acuerdo en que sus programas declinarían si el aporte federal fuese eliminado. Cerca de una tercera parte cree que su programa estatal debería terminar y la mitad cree que una severa reducción en su programa va a ocurrir si la ayuda federal fuese eliminada. Solamente el $42 \%$ de los programas estatales de U\&CF ha habilitado la legislación que autoriza asistencia financiera y técnica. Otras entidades que proveen asistencia fueron identificadas con el Servicio de Extensión Cooperativo, citado muy frecuentemente. 


\section{Appendix 1. Selected questions used in this article from the study questionnaire: state urban and community forestry program attributes and approaches in $2002 .^{2}$}

3) Does your state have enabling legislation specifically authorizing U\&CF technical and/or financial assistance?
$\square$ No $24(58.5 \%)$
$\square$ Yes $17(41.5 \%) n=41$

3a) (If yes) If financial assistance is authorized, what is the name(s) of the enabling legislation for financial assistance and what year(s) was it passed?

$\square$ No $4(23.5 \%)$

$\square$ Yes $13(76.5 \%) n=17$

Legislation title(s): Act 187, California Urban Forest Act of 1978, Delaware U\&CF Legislation, ID Forestry Act, Hometown, Community Forestry

Fund, Urban \& Community Forestry, MN ReLeaf Community Forestry Grant Program, Community and Urban Forestry Program, HB 2913,

Cooperative Urban Forestry Program, 1991-1993 Budget Bill

Year(s) passed: mean 1992 (median 1993, mode 1991, range 1978 to 2001)

3b) If technical assistance authorized, what is the name(s) of the enabling legislation for technical assistance and what year(s) was it passed?

Is technical assistance authorized? $\quad \square$ No $3(17.6 \%) \quad \square$ Yes $14(82.4 \%) n=17$

Legislation title(s): California Urban Forest Act of 1978, Delaware U\&CF Legislation, ID Forestry Act, Urban Forestry Assistance, Bureau of Forestry, Powers and Duties, Urban \& Community Forestry, Community and Urban Forestry Program, HB 2913, Technical Assistance

Year(s) passed: mean 1988 (median 1989, mode 1993, range 1978 to 1998)

3c) (If no) What best describes how the U\&CF program is enabled?

$\square$ Through general state forestry enabling legislation

$11(45.8 \%)$

$\square$ The federal U\&CF program is used to enable or justify the U\&CF program

$\square$ Other

5) What types of U\&CF technical assistance does your state program include, how frequently do they occur, and who provides it? (answer all as applicable)

See data in Table 4

6) Approximately how many communities did the state U\&CF program assist in 2002? (answer all as applicable)

Total number of communities that received federal grants or cost-share assistance

Mean 19.1 (median 18, mode 0 , range 0 to 74 ) $n=36$

Total number of communities that received state grants or cost-share assistance

Mean 14.4 (median 0, mode 0 , range 0 to 70 ) $n=40$

Total number of communities that received technical assistance

Mean 165.6 (median 110, mode 228, range 16 to 650 ) $n=33$

Total number of community assists (note: include in the total all assists per community; thus, if community A had three technical and one financial assist, add four into total)

Mean 356.3 (median 240, mode 150, range 35 to 1509 ) $n=25$

7) What other agencies or entities provide $\mathbf{U} \& \mathbf{C F}$ technical assistance in your state? (check all that apply and circle the frequency of assistance for each as applicable)

See data in Table 5

11) Does your agency administer Federal Cooperative Forestry Assistance Challenge Cost-share grants to communities?

$\square$ No $7(17.1 \%)$

$\square$ Yes $34(82.9 \%) n=41$

11a) (If yes) what was the amount of grant money from above in 2002 ?

$\$$ Total $\$ 4,656,469$, mean $\$ 160,568$ (median $\$ 125,000$; range, 9 to 535,000$) n=29$

Total national estimate all 50 states $\$ 6,657,693$

11b) If known, approximately how many dollars were leveraged from Federal Cooperative Forestry Assistance Challenge Cost-share grants in 2002?

$\$$

Total $\$ 4,460,444$, mean $\$ 193,932$ (median $\$ 150,000$; range 15 to 739,000$) n=23$

Total national estimate all 50 states $\$ 8,041,097$

12) Does your agency provide financial assistance to communities for $U \& C F$ activities from state monies?
$\square$ No $25(61.0 \%)$
$\square$ Yes $16(39.0 \%) n=41$

12a) (If yes) How many state dollars were allocated for U\&CF financial assistance to communities in 2002?

$\$$ Total $\$ 3,522,036$, mean $\$ 251,574$ (median $\$ 166,000$; range 0 to $1,125,000) n=14$

Total national estimate all 50 states $\$ 4,908,761$

12b) If known, approximately how many dollars were leveraged from state-financed grants in 2002 ?

$\$$ Total $\$ 4,133,596$, mean $\$ 295,257$ (median $\$ 153,000$; range 0 to $1,175,000) n=14$

Total national estimate all 50 states $\$ 5,761,109$

12c) What sources of state funding were used in 2002 for U\&CF financial assistance? (check all that apply)

$\square$ General fund $\quad 5(35.7 \%)$

$\square$ Dedicated account $\quad 7(50.0 \%)$

$\square$ Foundation/trust fund $\quad 4(28.6 \%)$

$\square$ Other $\quad 4(28.6 \%) n=14$

(Note: Sum greater than $100 \%$ from multiple responses)

Other: Investor-owned Utilities Companies, Dedicated sales tax supports agency, DOT Funds, OEPA Air Pollution Fines 
13) How is the state U\&CF program funded and what was the total annual amount of money in 2002 for all aspects of your program (e.g., staff, grants, overhead, publications, etc.)? (check all that apply and enter annual amount)

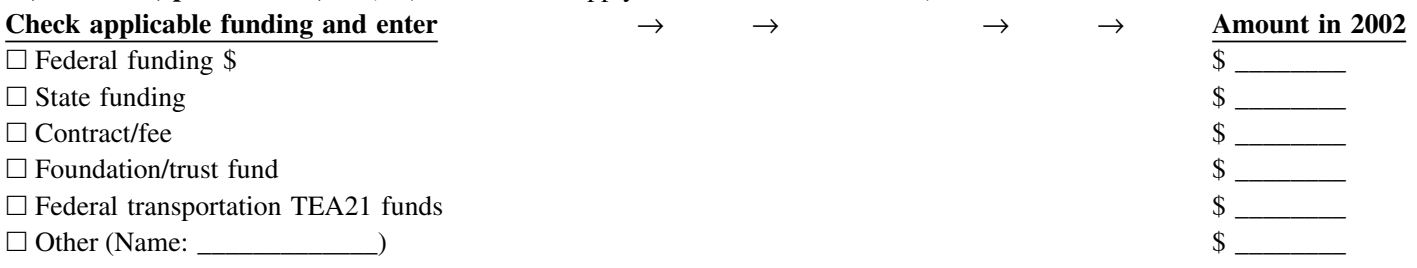

Other (Name: state transportation funding, license plate fees, investor-owned utilities, local match, consolidated match, Arbor Day sponsors) See data in Table 2

14) How adequate are the funding sources identified in question 13 to currently meet the needs to conduct the U\&CF program based on identified program needs?
$\square$ Very adequate
$2(5.1 \%)$
$\square$ Adequate
$14(35.9 \%)$
$\square$ Inadequate
$21(53.8 \%)$
$\square$ Very inadequate
$2(5.1 \%) n=39$
$\square$ Unsure
(two of 41 responses)

14a) If funding is less than adequate, what percent increase in funding do you think is needed?
$\%$
$60.9 \%$ (median $40 \%$, mode $30 \%$, range $20 \%$ to $400 \%$ ) $n=22$

14b) Describe what cannot be done as a result of less than adequate funding?

Adequate levels of: grants (13), staffing (8), technical assistance (6), council support (2), reaching underserved populations (1), research (1), outreach/publicity (1), travel (1)

18) What best describes how your state government funds the U\&CF program? (check one)

$\square$ Contingent on annual or biennial reauthorization of funding from the state legislature

$$
7(17.5 \%)
$$

$\square$ Annual baseline funding was established through state legislation and not subject to periodic reauthorization

$1(2.5 \%)$

$\square$ Legislation does not specifically earmark an appropriation $\quad 14(35.0 \%)$

$\square$ No state government funds are allocated for the U\&CF program $\quad 16(40.0 \%)$

$\square$ Other

$2(5.0 \%) n=40$

(Describe: Dedicated 1/8 of 1\% sales tax supports agency U\&CF funding in line item agency budget, Coordinator and some partial salaries come out; all other funds from outside sources)

24) If federal $\mathrm{U} \& C F$ funding were eliminated, would your program likely continue? (check one answer)
$\square$ No
$13(31.7 \%)$
$\square$ Yes at the current level
$0(0.0 \%)$
$\square$ Yes, but at a slightly reduced level
$5(12.2 \%)$
$3(7.3 \%)$
$\square$ Yes, but at a severely reduced level
$20(48.8 \%) n=41$

25) Overall, what level of impact would elimination of federal funding have on the state U\&CF program? (check one answer)
$\square$ Very high
$30(75.0 \%)$
$\square$ High
$7(17.5 \%)$
$\square$ Moderate
$1(2.5 \%)$
$\square$ Low
$1(2.5 \%)$
$\square$ Very low
$1(2.5 \%) n=40$

26) Overall, what level of impact would elimination of federal funding have on local U\&CF programs in your state? (check one answer)

$\begin{array}{lc}\square \text { Very high } & 14(35.0 \%) \\ \square \text { High } & 15(37.5 \%) \\ \square \text { Moderate } & 8(20.0 \%) \\ \square \text { Low } & 0(0.0 \%) \\ \square \text { Very low } & 3(7.5 \%) n=40\end{array}$

${ }^{\mathrm{z}}$ All questions at www.uwsp.edu/cnr/faculty/hauer/Files/Hauer\%20Dissertation.pdf. 